\title{
Reviewing Financial Literacy for SMEs and Entrepreneurs in Developing Economies
}

\author{
Juma Buhimila Mabula \\ PhD Scholar, Harbin Institute of Technology, Harbin, Heilongjiang, China
}

\begin{abstract}
As financial literacy studies gain thrust in the world concern on developing economy financial literacy rises. This study attempted to review financial literacy for SMEs and entrepreneurs in developing economies in the past decade. The review uncovers a dearth of literature on this phenomenon. There is a great disparity into financial domain measurement contents, methodology and the sampling frame. All these calling for immediate intervention by researchers, governments, financial institutions, and bilateral agents dealing in various financial literacy initiatives.
\end{abstract}

Keywords: financial literacy, Developing economies, construct definition

\section{Introduction}

A concern of financial literacy around the world has recently thrusted. This is due to its undeniable eminence importance of the phenomenon it offers to the economy. [1] argues that understanding the relationship between knowledge of personal financial behavior is increasingly recognized as an area of critical importance. There are enormous numbers of financial literacy studies at individual level in various economic constructs. Individual then apply the financial knowledge and skill they have into various financial transaction for making right decisions.

One of the emanating facet by many scholar especially in the developing economy is viewing financial literacy in terms of firms they own or manage. It is plainly truth that having managers who are well placed into making profound financial decisions in the conduct of their ventures have a positive impact in their sustainability. [2] contends that in business, decision making needs to be rational and be premised on available information. This implies it is imperative that manager of business and individual should have reasonable degree of knowledge related to the available information to make profound decision.

With the advancement of information and communication technology the cost differential of serving the poor customers has fallen and financial institutions now perceive significant opportunities in the SME sector in developing economies [3] . Nevertheless financial access in developing economies is still a problem. But still the general literacy in developing countries is lower and running a business in these economies exposes owners/managers to distinct challenges to manage.

Considering the role of SMEs and entrepreneurs in the developing economy, where by the highest percentage of the economy is controlled by these firms. Financial literacy as one of the key driver to the success of businesses is of big concern. In light of the changing business environment, financial literacy is considered to be the capability to adequately oversee financial resources over the business lifecycle and connect effectively with financial products and services. [4]. The management of firm financial resources requires knowledge, skill, attitude and experience with the goal to dealing with the survival of the firm, profit maximization, sales maximization, capturing a market share, minimizing staff turnover and internal conflicts; and maximizing wealth.

The term financial literacy, financial education, financial knowledge and financial capability in most studies tend to be used interchangeably. Up to this time there is no standard measure of financial literacy owing to the researcher to devise various ways of defining and measuring it. It is even worse when it comes to SMEs Financial literacy because this needs the researcher to customize their financial literacy understanding into business manner. Lacking a profound standard causes a big variation in the way different scholar approach various studies in financial literacy for SMEs.

In general term there is dearth of financial literacy studies in developing economies and especially Africa, the disparity of the study and especially most of them being located in just some few countries and the rest countries has never had such kind of studies. In this study we offer a review of the financial literacy studies in connection to SMEs or entrepreneurships in developing economies.

\section{Financial Literacy for SMEs}

Literacy is for creatures with cognitive ability like human being, that's why we talk of personal financial literacy. The concept of financial literacy for SMEs has been emanated based on its own definition. This is because of their small size and being led by few owner managers. Therefore the manager level of financial literacy can easily be translated into their businesses. Examining financial literacy of SMEs we need to widen the scope of personal finance ability to translate knowledge and skills into their business.

The Bank Association of South Africa [5] defines financially literacy for SMEs as one which has the following qualities: first has an adequate level of personal entrepreneurial competencies, personal finance skills, and

Volume 5 Issue 6, June 2016 www.ijsr.net 


\section{International Journal of Science and Research (IJSR) \\ ISSN (Online): 2319-7064}

Index Copernicus Value (2013): 6.14 | Impact Factor (2015): 6.391

business management skills; has an appropriate level of understanding of functional financial management systems. Second, has appropriate level of understanding of SME life-cycle funding and other financial service requirements. third, understands legal, regulatory and tax issues as they relate to financial matters and lastly understands the range of legal recourses it can resort to when necessary, and namely, in case of bankruptcy or other situations of financial distress.

Either financially literate SME owner/manager is defined as someone who knows what are the most suitable financing and financial management options for his/her business at various growth stages of his/her business; knows where to obtain the most suitable products and services; and interacts with confidence with the suppliers of these products and services. He/she is familiar with the legal and regulatory framework and his/her rights and recourse options. [6] .

Therefore SMEs financial literacy, states of manager's ability to translate their personal finance into a business venture context. With SMEs the concept of financial literacy is widened. Actually in every definition of financial literacy for SMEs there is an emphasis on the financial management of the venture.

\section{Approach of the Review}

We the analysis of prior studies applied by [7] they emphasized of construct validation. The construct validation follow four main steps: defining the construct, item content, method of measure and the scoring procedures. At first we need to define the aspect of the construct and differentiate it from other related concepts. Secondly is to determine the instrument content and this always use relevant domains as indicators of a given construct. Thirdly, we are concerned by the applied measuring procedures and this may include data collection strategies, and the design of the instruments used in collecting data. Then lastly, instrument scoring for rating, communication, and consistency and interpreting the results needs to be established.
We adopt this mode to analyze the various studies of SMEs financial literacy in developing economies. [8] also used the construct validity to measure general financial literacy around the world. But we modify the construct to suit firm's financial literacy in developing economies.

In the review and measurement financial literacy of firms we assess firm financial literacy studies on the basis of whether a general definition of financial literacy was provided, a specific definition of firm financial literacy was offered and whether multiple terms were used to define the same concept. The coding procedure bases on whether the construct is clearly defined, at least somewhat conceptually exemplified beyond the operational measure, or whether an implied definition was offered.

Also each study was examined based on the financial domain content of each construct. After evaluating the commonality of firm financial literacy the following categories emerged: budgeting and planning, financing and loan, saving/investing and protection.

On instrument structure we examine the number of instruments items and the data collection method and whether it employed scientific analysis or not.

To address the rating issue, we examine how the researcher came up with determination of the financial literacy level of the firm.

We also capture the sample size that was used, target audience, the location of the study, and the nature of the study.

The criteria for this study selecting studies included in the analysis firs of all the study has to have been undertaken in past decade, secondly the study was supposed to connect financial literacy and enterprise management variables or entrepreneurship and it should cover analysis in the developing economies. Based on our decent internet search we found 12 studies which were included in the review.

Table 1: Construct analysis of the reviewed studies

\begin{tabular}{|c|c|c|c|c|c|c|c|c|c|c|c|c|c|c|}
\hline \multirow{2}{*}{$\begin{array}{l}\mathrm{N} \\
\mathrm{o}\end{array}$} & \multicolumn{2}{|c|}{ Study Details } & \multicolumn{4}{|c|}{ Construct definition } & \multirow{2}{*}{$\begin{array}{c}\begin{array}{c}\text { Finan } \\
\text { cial } \\
\text { domai } \\
\text { n } \\
\text { Conte } \\
\text { nt }\end{array} \\
\text { NI }\end{array}$} & \multicolumn{2}{|c|}{ Structure } & \multirow{2}{*}{$\begin{array}{c}\text { Rating } \\
\text { FLL } \\
\end{array}$} & \multicolumn{4}{|c|}{ Others } \\
\hline & Reference & Study & 0 & $:-1$ & FKL & FSSAB & & DTM & DAM & & $\infty n$ & TS & $1-<$ & LC \\
\hline 1 & $\begin{array}{c}\text { Kimani \&Ntoiti, } \\
2015\end{array}$ & $\begin{array}{l}\text { Effect of FL on } \\
\text { performance of } \\
\text { youth led } \\
\text { enterprises: a case } \\
\text { of equity group } \\
\text { foundation } \\
\text { training } \\
\text { programme in } \\
\text { Kiambu district }\end{array}$ & 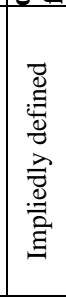 & $\overleftarrow{z}$ & FL & NA & 15 & survey & $\begin{array}{l}\text { descrip } \\
\text { tive } \\
\text { and } \\
\text { regress } \\
\text { ion } \\
\text { analysi } \\
\mathrm{s}\end{array}$ & $\begin{array}{l}\text { increas } \\
\text { ed FL }\end{array}$ & 70 & $\begin{array}{c}\text { specifi } \\
\text { c } \\
\text { (youth } \\
\text { led } \\
\text { enterpr } \\
\text { ises }\end{array}$ & $\begin{array}{ll}\text { d } \\
\text { d }\end{array}$ & kenya \\
\hline 2 & $\begin{array}{l}\text { Eniola\&Enteban } \\
\text { g, } 2016\end{array}$ & $\begin{array}{l}\mathrm{Fl} \text { and SMEs } \\
\text { performance }\end{array}$ & 迡 & 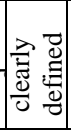 & FL & $\begin{array}{c}\text { Categor } \\
\text { ised } \\
\text { definiti } \\
\text { on }\end{array}$ & NA & $\begin{array}{c}\text { review of } \\
\text { Literatur } \\
\text { e }\end{array}$ & $\begin{array}{c}\text { descrip } \\
\text { tive } \\
\text { review }\end{array}$ & NA & $\begin{array}{l}\mathrm{N} \\
\mathrm{A}\end{array}$ & NA & $\overleftrightarrow{z}$ & Nigeria \\
\hline
\end{tabular}




\section{International Journal of Science and Research (IJSR) \\ ISSN (Online): 2319-7064}

Index Copernicus Value (2013): 6.14 | Impact Factor (2015): 6.391

\begin{tabular}{|c|c|c|c|c|c|c|c|c|c|c|c|c|c|c|}
\hline 3 & $\begin{array}{c}\text { Nyamboga et.al, } \\
2014\end{array}$ & $\begin{array}{l}\text { Assessment of FL } \\
\text { on loan } \\
\text { repayment bu } \\
\text { SMEs in Ngara, } \\
\text { Nairobi County }\end{array}$ & 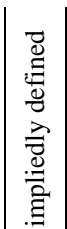 & 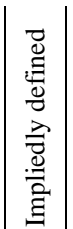 & FL & NA & 15 & $\begin{array}{l}\text { Survey, } \\
\text { Self } \\
\text { Administ } \\
\text { ered }\end{array}$ & $\begin{array}{l}\text { descrip } \\
\text { tive } \\
\text { and } \\
\text { regress } \\
\text { ion } \\
\text { analysi } \\
\mathrm{s}\end{array}$ & NA & 30 & $\begin{array}{l}0 \\
:=0 \\
\mathscr{D} \\
\text { क }\end{array}$ & శ్ & Kenya \\
\hline 4 & $\begin{array}{c}\text { Adomako\&Dans } \\
\text { o, } 2014\end{array}$ & $\begin{array}{l}\text { FL and firm } \\
\text { performance: the } \\
\text { moderating role } \\
\text { of financial } \\
\text { capital } \\
\text { availability and } \\
\text { resource } \\
\text { flexibility }\end{array}$ & 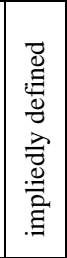 & 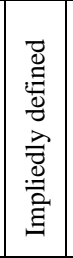 & FL & NA & $\begin{array}{c}4 \\
\text { conten } \\
\text { ts }\end{array}$ & $\begin{array}{l}\text { survey, } \\
\text { Telephon } \\
\text { e, then } \\
\text { Self } \\
\text { Administ } \\
\text { ered }\end{array}$ & $\begin{array}{l}\text { Scienti } \\
\text { fic } \\
\text { analysi } \\
\text { s }\end{array}$ & $\begin{array}{l}\text { only } \\
\text { measur } \\
\mathrm{e} \\
\text { reliabili } \\
\text { ty of } \\
\text { the } \\
\text { result }\end{array}$ & $\stackrel{\infty}{\stackrel{\sim}{े}}$ & $\underset{0}{\stackrel{\pi}{0}}$ & హิ & Ghana \\
\hline 5 & $\begin{array}{c}\text { Nunoo\&Andoh, } \\
2012\end{array}$ & $\begin{array}{l}\text { Sustaining SMEs } \\
\text { through financial } \\
\text { service } \\
\text { utilization: does } \\
\text { FL Matter? }\end{array}$ & 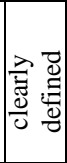 & 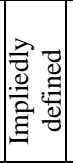 & FL & $\begin{array}{l}\text { Categor } \\
\text { ised } \\
\text { definiti } \\
\text { on }\end{array}$ & NA & $\begin{array}{l}\text { interview } \\
\text {, Survey }\end{array}$ & $\begin{array}{l}\text { Scienti } \\
\text { fic } \\
\text { analysi } \\
\text { s }\end{array}$ & NA & $\stackrel{\wp}{n}$ & $\frac{\pi}{0}$ & $\begin{array}{l}\mathrm{N} \\
\mathrm{A}\end{array}$ & Ghana \\
\hline 6 & Fatoki, 2014 & $\begin{array}{c}\text { The FL of micro } \\
\text { entrepreneurs in } \\
\text { SA }\end{array}$ & 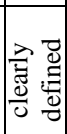 & 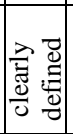 & FL & NA & 58 & $\begin{array}{l}\text { Survey, } \\
\text { Self } \\
\text { Administ } \\
\text { ered }\end{array}$ & $\begin{array}{l}\text { descrip } \\
\text { tive } \\
\text { statistic } \\
\mathrm{s}\end{array}$ & $\begin{array}{l}\text { low } \\
\text { level }\end{array}$ & $\begin{array}{l}\mathrm{N} \\
\mathrm{A}\end{array}$ & $\frac{\pi}{0}$ & $\begin{array}{l}\mathrm{N} \\
\mathrm{A}\end{array}$ & $\begin{array}{l}\text { Ssouth } \\
\text { Africa }\end{array}$ \\
\hline 7 & $\begin{array}{c}\text { Drexler et. Al. } \\
2014\end{array}$ & $\begin{array}{c}\text { Keeping it simple: } \\
\text { financial literacy } \\
\text { and the Rules of } \\
\text { Thumb }\end{array}$ & 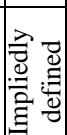 & 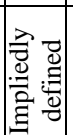 & FL & NA & NA & $\begin{array}{l}\text { experime } \\
\text { ntal }\end{array}$ & $\begin{array}{l}\text { Scienti } \\
\text { fic } \\
\text { analysi } \\
\text { s }\end{array}$ & $\begin{array}{l}\text { increas } \\
\text { ed FL }\end{array}$ & $\stackrel{n}{=}$ & 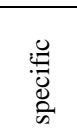 & $\begin{array}{l}\mathrm{N} \\
\mathrm{A}\end{array}$ & $\begin{array}{l}\text { Domini } \\
\text { can } \\
\text { Republ } \\
\text { ic }\end{array}$ \\
\hline 8 & Plakalović, 2015 & $\begin{array}{c}\text { FL of SMEs } \\
\text { managers }\end{array}$ & 正 & त文 & FL & NA & NA & Survey & $\begin{array}{l}\text { descrip } \\
\text { tive }\end{array}$ & $\begin{array}{c}\text { low } \\
\text { level of } \\
\text { FL }\end{array}$ & 51 & $\stackrel{\bar{D}}{\bar{D}}^{\overline{0}}$ & $\begin{array}{l}\mathrm{N} \\
\mathrm{A}\end{array}$ & $\begin{array}{l}\text { republi } \\
\text { c of } \\
\text { Srpska }\end{array}$ \\
\hline 9 & Suchuahi & $\begin{array}{l}\text { Determinants of } \\
\text { FL of micro } \\
\text { entrepreneurs in } \\
\text { Davao city }\end{array}$ & 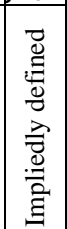 & 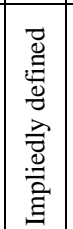 & FL & NA & 4 & $\begin{array}{l}\text { Survey, } \\
\text { Self } \\
\text { Administ } \\
\text { ered }\end{array}$ & $\begin{array}{c}\text { descrip } \\
\text { tive } \\
\text { and } \\
\text { regress } \\
\text { ion } \\
\text { analysi } \\
\mathrm{s}\end{array}$ & $\begin{array}{l}\text { level of } \\
\text { FL } \\
\text { determi } \\
\text { ned }\end{array}$ & 8 & 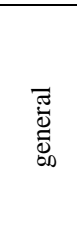 & $\begin{array}{l}\mathrm{N} \\
\mathrm{A}\end{array}$ & $\begin{array}{c}\text { Philipi } \\
\text { nes }\end{array}$ \\
\hline 10 & Barte, 2012 & $\begin{array}{l}\text { FL in Micro- } \\
\text { enterprises: The } \\
\text { case of cebu fish } \\
\text { vendors }\end{array}$ & 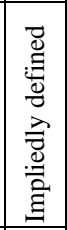 & 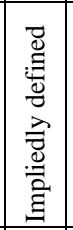 & $\begin{array}{c}\mathrm{FL}=\mathrm{Fs} \\
\text { kills }\end{array}$ & NA & 4 & $\begin{array}{c}\text { Survey, } \\
\text { Self } \\
\text { Administ } \\
\text { ered }\end{array}$ & $\begin{array}{c}\text { descrip } \\
\text { tive } \\
\text { and } \\
\text { statistic } \\
\text { al } \\
\text { analysi } \\
\text { s }\end{array}$ & $\begin{array}{c}\text { low } \\
\text { level of } \\
\text { FL }\end{array}$ & 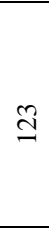 & 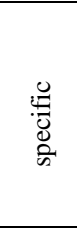 & $\stackrel{\sim}{\stackrel{\sim}{d}}$ & $\begin{array}{c}\text { Philipi } \\
\text { nes }\end{array}$ \\
\hline 11 & $\begin{array}{c}\text { Mutegi\&Njeru, } \\
2015\end{array}$ & $\begin{array}{l}\text { FL and its impact } \\
\text { on loan } \\
\text { repayment by } \\
\text { small and medium } \\
\text { enterpreneurs }\end{array}$ & 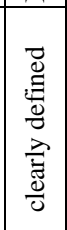 & 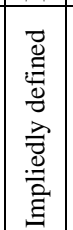 & FL & NA & 11 & $\begin{array}{l}\text { survey, } \\
\text { questinn } \\
\text { aire }\end{array}$ & $\begin{array}{l}\text { descrip } \\
\text { tive } \\
\text { and } \\
\text { statistic } \\
\text { al } \\
\text { analysi } \\
\text { s }\end{array}$ & $\begin{array}{l}\text { increas } \\
\text { ed FL }\end{array}$ & ల & $\begin{array}{l}0 \\
: 0 \\
0 \\
0\end{array}$ & ষ্ণ & Kenya \\
\hline 12 & $\begin{array}{c}\text { Kalekye\&Memb } \\
\text { a, } 2013\end{array}$ & $\begin{array}{l}\text { The role of FL on } \\
\text { profitability of } \\
\text { women owned } \\
\text { enterprises in } \\
\text { Kitui Town }\end{array}$ & 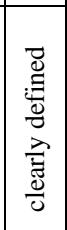 & 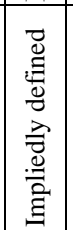 & FL & NA & 4 & $\begin{array}{l}\text { survey, } \\
\text { questinn } \\
\text { aire }\end{array}$ & $\begin{array}{c}\text { descrip } \\
\text { tive } \\
\text { and } \\
\text { statistic } \\
\text { al } \\
\text { analysi } \\
\mathrm{s}\end{array}$ & $\begin{array}{c}\text { implied } \\
\text { ly } \\
\text { determi } \\
\text { ned }\end{array}$ & 76 & 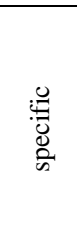 & $\begin{array}{l}\mathrm{N} \\
\mathrm{A}\end{array}$ & Kenya \\
\hline
\end{tabular}

Source: Author Review

NB: the explanation of the acronyms used in the table are given in appendix

Results from the Table of Analysis:

Among of the analyzed studies three of the studies $[2,9$, 10] , they analyze the impact of financial literacy on performance of the firm. $[11,12]$ relate examine financial literacy on loan repayment ability of a special trained group. [13] conducted a examined financial literacy on new venture survival. [3] conducted a study on the impact of financial literacy on firm financial service utilization. [14] assessed the level of micro entrepreneurs in South Africa. [15] present examination of rule of thumb training results on financial literacy. [16, 17] determined the level of financial literacy of micro entrepreneurs of specific groups (davao city and Cebu
Fish Vendors). [18] the only study specifically examined the role of financial literacy on profitability of women owned firms.

At first level the analysis examined whether the definition of financial literacy was clearly defined, impliedly defined or not defined at all. $50 \%$ of the reviewed studies clearly attempted to include the definition of financial literacy and $50 \%$ of the studies impliedly defined financial literacy. Only $16 \%$ of all these studies clearly defined the specific definition of financial literacy for SMEs or ventures, 73\% impliedly defined SME financial literacy and $8 \%$ (1) study

\section{Volume 5 Issue 6, June 2016}




\section{International Journal of Science and Research (IJSR) \\ ISSN (Online): 2319-7064}

Index Copernicus Value (2013): 6.14 | Impact Factor (2015): 6.391

didn't seem to show any concern about defining financial literacy for SMEs.

Almost all studies emphasized on financial literacy concept except one. One study used financial literacy and skills interchangeably. Therefore the concept of financial literacy in these studies is not viewed to be anonymous phenomenon.

To understand contents and the process of financial literacy it is important to analyze the concept of financial literacy into various variables. From the analysis on two studies attempted to categorize financial literacy into knowledge and understanding, skills, attitudes and confidence and ultimately behavior. $[3,4]$

Varying degree of financial contents was revealed in these studies. The most featured domains based on budgeting and planning, financing, borrowing, investing and saving, preparation of financial statements and banking services. There is no consistency on the contents of variables included on analyzing financial literacy. But few studies didn't reveal any variable contents on attempt to measure the level of financial literacy.

Looking on the instruments used 10 out of 12 studies used survey method mostly employed a self-administered questionnaire. One study was experimental and the other was the review of literature. And on attempt to analyze data only three studies had a scientific analysis with a scientific model analyzed. The rest of the studies used descriptive statistics and simple regression analysis and one study which were just a review of literature. This the popularity of survey in financial literacy studies but again the limited number of scientific analysis in the concept of financial literacy-firm relationship.

$67 \%$ of the reviewed studies attempted to show how analyzed financial literacy of either increasing or decreasing or at certain level, the reminder of the study didn't attempt.

The sample space varied from 30 up to 1,193 averaging to 253 items. $50 \%$ of the studies were of the specific population of either women, fish vendors, and group foundation beneficiaries the remaining half was general population study. Also 50\% attempted to show the number of the entire population the reminder didn't.

The location of study is dispersed and only few counties represented we had 4 from Kenya, 2 from Ghana, 2 from Philippines, while Nigeria, Dominican Republic, South Africa and republic of Srpska each had one studies.

\section{Financial Literacy for SME measurement Limitations identified}

- Many studies though attempted to make the general definition of financial literacy many of them failed to have a concrete definition of financial literacy for SMEs. Moreover generalizing the financial literacy variables and its specific impact on SMEs endeavor still is a big problem. For instance financial knowledge and understanding has differing connection to SMEs performance as does financial skill and attitude.

- The review also unearths a greater disparity of financial domain contents in terms of number of items included and the items themselves. The number of items varying from 4 to 58 is an alarming situation when it comes to making standardized arguments.

- The studies reviewed very few of them employed scientific analysis; this poses a great danger of misleading and non-robust results from many studies.

- The lower the sample displayed in the analysis may also pose a threat of many studies not being representative ultimately brings about questionable results.

- The studies locations reveal that first of all these studies are very few, secondly they dispersedly located into Africa and Asia. Calling for a great challenge for researchers to investing into studying this phenomenon because it is of paramount importance in the economic developments and performance of firms in developing economies.

\section{Conclusion}

As it is to the general literacy developing economies has a long way to achieve notable attainment in financial literacy. More efforts need to be implemented by the governments to come up with initiatives to sensitize the importance of financial literacy. Governments needs to work together with bilateral economic agencies and international organizations like Fine\$cope and Worldbankwhich has done a lot of research and instituted many initiatives towards individuals and firm's financial awareness. With conducive institutional framework the private sector especially financial institutions can achieve a great deal into financial literacy by offering training connected to the products they offer to the market.

\section{References}

[1] Robb, C.A. and A. Woodyard, Financial knowledge and best practice behavior. Journal of Financial Counseling and Planning, 2011. 22(1).

[2] Eniola, A., H. Entebang, and O.B. Sakariyau, Small and medium scale business performance in Nigeria: Challenges faced from an intellectual capital perspective. International Journal of Research Studies in Management, 2015. 4(1).

[3] Nunoo, J. and F.K. Andoh. Sustaining Small and Medium Enterprises through Financial Service Utilization: Does Financial Literacy Matter? in Annual Meeting. 2012.

[4] Eniola, A.A. and H. Entebang, Financial literacy and SME firm performance. International Journal of Research Studies in Management, 2015. 5(1).

[5] Messy, F.-A. and C. Monticone, The status of financial education in Africa. 2012.

[6] Economic, U.N.D.o. and U.N.D.o.P. Information, The millennium development goals report 2009. 2009: United Nations Publications.

[7] Pedhazur, E., Schmelkin, LP (1991). Measurement, design, and analysis: An integrated approach. Hillsdale, N] : Erlbaum, 1991. 


\section{International Journal of Science and Research (IJSR) \\ ISSN (Online): 2319-7064}

Index Copernicus Value (2013): 6.14 | Impact Factor (2015): 6.391

[8] Huston, S.J., Measuring financial literacy. Journal of Consumer Affairs, 2010. 44(2): p. 296-316.

[9] Kimani, P.M. and J. Ntoiti, Effects of Financial Literacy on Performance of Youth Led

[10] Enterprises: A Case of Euity Group Foundation Training Program in Kiambu County. international Journal of social Management and entrepreneurship, 2015. 2(1): p. 218-231.

[11] Adomako S, D.A., Financial Literacy and firm Performance: the Moderating role of financial Capital availability and Resource Flexibility. International Journal of Management and Organizational studies, 2014. 3(4).

[12] Mutegi K.H, Njeru P.W, and N. T.O, Financial literacy and its impact on loan repayment by small and medium enterpreneurs. international Journal of economics, commerce and management, 2015. III(3).

[13] Nyamboga T.O, et al., An assessment of financial literacy on loan repayment by SMEs in Ngara, Nairobi county. Journal of Finance and Accounting, 2014. 5(12).

[14] Wise, S., The impact of financial literacy on new venture survival. International Journal of Business and Management, 2013. 8(23): p. 30.

[15] Olawale, F., The financial literacy of Micro Enterpreneurs in South Africa. Journal of social sciences, 2014. 42(2): p. 7.

[16]Drexler, A., G. Fischer, and A. Schoar, Keeping it simple: Financial literacy and rules of thumb. American Economic Journal: Applied Economics, 2014. 6(2): p. 1-31.

[17] Sucuahi, W.T., Determinants of financial literacy of micro entrepreneurs in Davao City. International Journal of Accounting Research, 2013. 1(1): p. 44-51.

[18] Barte, R., Financial Literacy in Micro-Enterprises: The Case of Cebu Fish Vendors. Philippine Management Review, 2012. 19.

[19] Kalekye, P.N. and F. Memba, The Role of Financial Literacy on the Profitability of Women Owned Enterprises in Kitui Town, Kitui County, Kenya.

\section{Author Profile}

Juma Buhimila Mabula, PhD Scholar Harbin Institute of Technology china, Assistant Lecturer Mzumbe University Tanzania

\section{Appendix}

Explanation of the Acronyms Used in the Table of Analysis

Gdfn=general definition of financial literacy

Sdfn=specific definition of financial literacy for SMEs

$\mathrm{FLK}=$ whether financial literacy used interchangeably to other concepts like financial knowledge, financial skills, financial capability, etc

FSSAB =categorization of financial knowledge and understanding, skills, attitudes and behavior in defining financial literacy

$\mathrm{BP}=$ budgeting and planning

$\mathrm{FBL}=$ financing/ borrowing and loans

IS-investing and saving
$\mathrm{P}=$ protection

$\mathrm{NI}=$ number of instrument items

DTM=data collection method

DAM=Data analysis method

FLL=determination of financial literacy level, whether rating was used to identify the firm financial literacy (yes or no) and if an ordinal ranking was used (levels, like high to low grade)

TS=type of sample for study (general population, specific e.g. manufacturing firms, agricultural firms, etc

$\mathrm{SS}=$ study sample

$\mathrm{LC}=$ location

$\mathrm{NA}=$ not attempted 